\title{
MAKTSPILL I KHARTOUM
}

ET SKRITT MOT FRED OG DEMOKRATI?

Våren I986 ble det holdt frie valg i Sudan. Et nytt, demokratisk regime ble innført etter sytten år under militært diktatur. Men gleden ble kortvarig. Regimet var ustabilt og i juni I989 grep general Omar al-Bashir makten ved et militærkupp. 
TEKST: Claes-Johan L. Sørensen

MAKTSKIFTET BLE UMIDDELBART fordømt både regionalt og internasjonalt - ikke bare fordi det nye regimet var antidemokratisk, men også fordi det var islamistisk. Kuppet var imidlertid ikke et rent militærkupp. Det var iscenesatt sammen med The National Islamic Front (NIF) - et islamsk politisk parti under ledelse av Hasan al-Turabi. Turabi innrømmet selv overfor ввс і 1999 at han i hemmelighet planla kuppet sammen med Bashir for at den islamske bevegelsen ikke skulle bli mistenkeliggjort: "He [Bashir] went to the palace and I went to the prison so that the movement would not be exposed." ${ }^{\text {I }}$

Samarbeidet mellom Bashir og Turabi var spesielt i islamsk og arabisk sammenheng. Islamister og militære har sjelden omfavnet hverandre i denne del av verden. Det var derfor ikke overraskende at idyllen mellom Bashir og Turabi etterhvert slo sprekker. Etter en årelang maktkamp brøt de totalt i I999. Turabi ble siden satt i fengsel og sitter i dag i husarrest i sitt hjem i Khartoum.

Dette reiser flere spørsmål. For det første; hvorfor samarbeidet Bashir og Turabi i det hele tatt til å begynne med? Og hva var årsaken til bruddet? For det andre; hvilken type regime sitter igjen med makten i dag når islamistene er kastet ut? Og er dette et regime som går i demokratisk retning?

Utviklingen i Sudan siden I989 må sees i sammenheng med en rekke politiske og religiøse forhold som har preget regionen og landet siden I950-tallet. Kort fortalt har Sudan vært preget av ustabile regimer og borgerkrig siden selvstendigheten i 1956 . Videre har Sudan i samme periode opplevd fremveksten av politisk islam - personifisert i Hasan al-Turabi og organisert i den islamske bevegelse.

\section{Partnerskap mellom Turabi og Bashir}

Turabi har siden I950-tallet vært den ubestridte leder av den islamske bevegelsen i Sudan. ${ }^{2}$ Han er utdannet jurist fra Paris og London, snakker flytende engelsk og fransk, og har preget sudanesisk politikk og samfunnsliv i et halvt århundre. Fremfor alt er han pragmatikeren som inntil nylig elegant tilpasset seg de skiftende politiske forhold i Sudan. Bevegelsen er opprinnelig et utspring av Det muslimske brorskap i Egypt, men har under Turabis styring utviklet sitt eget politiske, sosiale og religiøse program. Likevel, organisasjonen ligger ideologisk tett opptil andre islamske bevegelser som krever innføring av en islamsk stat basert på den islamske loven shari' a. Den andre personen som preget 
Sudan på i99o-tallet var Omar al-Bashir. Da Bashir dukket opp på den politiske scenen i I989 var han en relativt ukjent størrelse. Han var riktignok høyt plassert i det militære, men hadde aldri hatt noen sentral politisk rolle i Sudan. At han klarte å gjennomføre et vellykket militærkupp skyldes sannsynligvis samarbeidet med Turabi. Sistnevntes politiske og organisatoriske erfaring var trolig avgjørende i planleggingen og gjennomføringen av kuppet. Likevel, Bashir var ingen nikkedukke for Turabi, men hadde sin klare agenda. Han, og mange med ham, var lei av det politiske rotet som hadde preget Sudan siden Numairi måtte gå i I985. Bashirs løsning var imidlertid brutal - han ville innføre en islamsk republikk, eliminere all politisk opposisjon og knuse opprøret i sør med militær makt.

Partnerskapet mellom Turabi og Bashir henger nøye sammen med deres felles målsetting. Selv om de hadde ulike politiske program, var mål og midler på sentrale punkter sammenfallende. En islamsk stat ville på den ene side oppfylle Turabis religiøse mål, og på den andre side gi Bashir makt og politisk kontroll i en islamsk tradisjon han kunne identifisere seg med. Bashir, som ville "rydde opp i rotet" som hadde pågått siden i985, var drevet av et personlig maktbegjær og troen på at islamske tradisjoner og verdier var veien å gå.

Bashir og Turabi var imidlertid også enige om virkemiddelet, nemlig å kuppe landet. At en militær skikkelse i Sudan ønsket et militærkupp er kanskje ikke overraskende, men at en politisk og religiøs skikkelse som Turabi ønsket det samme kan virke merkelig. Han hadde tross alt deltatt i den demokratiske politiske pros- essen fra i985. Kuppet viser etter min mening at demokratiske verdier ikke stikker dypt i verken Turabis politiske virkelighet eller i Sudans tradisjon og historie. For Turabi er demokrati ikke et mål i seg selv. Demokrati er heller ikke en vei å gå hvis det finnes andre veier som kan føre ham raskere frem til målet om en islamsk stat. Målet helliggjør middelet: hvis demokrati kan åpne for en islamsk stat, så omfavner Turabi demokratiet. Hvis et militært statskupp er mer effektivt, ja da omfavner han det. Dette er viktig å ha i mente, for her ligger kjernen til Sudans politiske utvikling på I990-tallet. Dette er en ekstrem pragmatisk holdning til politikk, men det gjør også Turabi forutsigbar. Man vet hva han vil og hvor han vil, og man kan dermed følge en viss logikk i hans handlingsmønster.

Konflikten som etter hvert skulle dukke opp dreide seg derfor ikke om mål eller virkemidler, men snarere om svært ulike religiøse motiver og forutsetninger. Mens Bashir var en religiøs tradisjonalist var Turabi en religiøs autoritet med en overbevisende religiøs tro. Turabi hadde med andre ord en religiøs overbevisning om at en islamsk stat vil være det beste for Sudan. Bashir derimot, hadde en politisk overbevisning om det samme. ${ }^{3}$

\section{Skilsmisse}

Problemene i Sudan ble langt fra løst under Bashirs jernneve. Riktignok fikk Sudan et mer stabilt regime enn tidligere, men borgerkrigen raste videre. Selv om Bashir klarte å undertrykke opposisjonen i nord, fant han raskt ut at han trengte regional og internasjonal diplomatisk støtte for å løse problemene i sør. En rekke fredsforhandlinger kom derfor $\mathrm{i}$ gang i regi av $\mathrm{IGAD}^{4}$ 
dessverre uten at det dempet Bashirs bruk av militære midler. Samtidig begynte Turabi å fremme forslag om å demokratisere landet. Ikke fordi han forandret mening om demokrati som sådan, men fordi han skjønte at demokrati ville styrke hans posisjon i forhold til Bashir. Etter press fra Turabi og tidligere NIF' ere ble derfor det

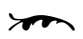

\section{Selv om Turabi og Bashar hadde ulike politiske program, var mål og midler sammenfallende.}

militære revolusjonsrådet oppløst i oktober I993. Formelt gikk dermed Sudan over fra et militært til et sivilt styre. Et “demokratisk" høydepunkt ble nådd tre år senere da det ble holdt presidentvalg I. april I996. Bashir ble valgt til president og Turabi ble valgt til "Speaker of Parliament." 5

Dermed startet maktkampen for fullt. I statsvitenskapelige termer ble det en kamp mellom den utøvende makt (Bashir) og den lovgivende makt (Turabi). Selv om målet om en islamsk stat teoretisk sett var realisert etter kuppet i I989 møtte Sudan en virkelighet som gjorde at Turabi og Bashir gled i fra hverandre. Mens Bashir ble realpolitikeren som forholdt seg vaklende til regionale og internasjonale aktører, ble Turabi islamisten som samlet lokal, nasjonal og regional støtte fra islamske organisasjoner og regimer. Sistnevntes islamistiske profil uroet naturlig nok både Egypt og UsA. Bashir øynet dermed muligheten for politisk og økonomisk støtte fra disse og begynte å stikke kjepper i hjulene for Turabi. Maktkampen toppet seg høsten I999 da
Turabi fremmet forslag om grunnlovsendringer som radikalt ville svekket Bashirs makt. Motrekket kom to uker senere. Bashir oppløste parlamentet, erklærte unntakstilstand, satte grunnloven ut av kraft og lot militære tropper ta over nasjonalforsamlingen.

Ikke overraskende fikk Bashir støtte fra både Egypt og Libya - Sudans sterkeste naboer. De hadde begge vært kritiske til Turabis islamistiske agenda, som i deres øyne kunne skape ustabilitet i regionen. Egypt og Libya (og forøvrig også USA) var mer komfortable med et solid og sterkt Sudan under Bashirs militære styre enn et pragmatisk og demokratisk/islamsk styre under Turabi. Det tidligere dårlige forholdet til Egypt ble dermed forbedret, mens Turabi ble totalt marginalisert. Han kom aldri mer på godfot med Bashir, og ble i mai 2000 sparket ut av politikken.

Selv om Turabi ble satt på sidelinja forholdt han seg ikke passiv. Han etablerte opposisjonspartiet Popular National Congress (PNC) i opposisjon til National Congress, det vil si nasjonalforsamlingen som han tidligere ledet. I et tilsynelatende febrilsk forsøk på å få oppmerksomhet gikk PNC sammen med tidligere erkefiende John Garang og Sudan People's Liberation Army (SPLA) og undertegnet et "memorandum of understanding” 20 . februar $200 \mathrm{I}$ Geneve. Dokumentet understreket at “Sudan's politiske, religiøse og kulturelle mangfold krever en sosial kontrakt som beskytter mot diskriminering på grunnlag av religion, kultur, rase, kjønn eller geografisk region." ${ }^{6}$ Dokumentet nevnte også at Sør-Sudan har en legitim rett til selvbestemmelse og at man må øke den “populære og pasifistiske motstand for at regimet [Bashir] skal gi avkall på sin total- 
itære politikk." 7

Vi skal ikke her spekulere i Turabis motiver for denne handlingen. Men to ting er nødvendig å trekke frem. For det første er det sannsynlig at Turabi kontaktet sPLA for å skape et bilde av seg selv som fredens mann - og dermed Bashir som tyrannen. Dette følger på mange måter Turabis pragmatiske vesen. For det andre var samarbeidet med spla faktisk ikke i direkte konflikt med Turabis tidligere uttalelser om kon-

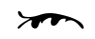

Sudan er mindre demokratisk i dag enn da Turabi satt ved roret. Men dette er i ferd med å forandre seg.

flikten i sør. Han har ved flere anledninger fremmet forslag om både regionalisering av landet og desentralisering av makt mellom nord og sør. ${ }^{8}$

Uansett motiver, avtalen med spla ble svært dårlig mottatt av Bashir. Sudanesiske sikkerhetsstyrker arresterte Turabi dagen etter at avtalen ble kjent. Samtidig ble PNC erklært forbudt. Tre måneder senere ble han flyttet fra cella til sitt eget hjem og sitter fremdels i husarrest der. Sudans president Bashir har dermed full politisk og militær kontroll over maktapparatet i Khartoum.

Turabis agenda gikk på tvers av både regionale og internasjonale interesser. Kommunikasjonen med andre islamske grupper og Iran satte sinnene i kok i Washington. For UsA var slike kontakter å regne som deler av et internasjonalt terroristnettverk. Det var blant annet etter amerikansk press at Osama bin Laden måtte forlate Sudan i 1996 etter å ha bodd der siden I99I og attpåtil fått sudanesisk statsborgerskap. Videre skapte Turabis åpne holding til Sør-Sudan problemer med Egypt. Ådesentralisere makten i Sudan kan i ytterste konsekvens føre til en deling av Sudan i to stater. Dette vil i så fall føre til at Egypt mister kontrollen over vannressurser fra Nilen. De to mest innflytelsesrike statene i forhold til Sudan var dermed svært negative til Turabi. Bashir fikk dermed et enormt press både regionalt og internasjonalt til å bryte kontakten med Turabi. Maktkampen mellom I996 og 1999 var derfor sterkt preget av eksterne krefter, selv om det på overflaten kunne se ut som en indre strid mellom to maktsyke menn.

Turabi og PNC er i dag kjørt helt ut på sidelinjen. Det er Bashir som råder med støtte fra både Egypt og USA. Bashir støttes også av sine afrikanske nabostater. Sudan har således bedre politiske relasjoner internasjonalt i dag enn på 9o-tallet. Det ironiske er likevel at Sudan er mindre demokratisk nå enn da Turabi satt ved roret. Men dette er i ferd med å forandre seg.

\section{Utsikter for demokrati}

Vi kan dermed konkludere med at demokrati ikke sees på som noe absolutt verdi, verken av Bashir eller andre aktører med innflytelse over Sudan, men som en av flere ulike måter å organisere landet på. Internasjonale forhold, økonomi og stabilitet veier ofte tyngre enn demokrati i Sudan. Likevel er det et sterkt ønske fra ulike aktører om å styrke demokratiet i landet. Lokalt dreier det seg om sterke partier som splm i sør og Northern Democratic Alliance (NDA) i nord. Sistnevnte er et opposisjonsparti med sentrale politikere fra perioden før I989. Regionalt har IGAD 
vært en solid pådriver for demokrati, og internasjonalt har en rekke NGo' er talt Sudans sak i mange år. Selv usA og Egypt har et ønske om en viss demokratiseringsprosess, så lenge “feil” personer ikke kommer i sentrale maktposisjoner. For å oppsummere skal vi derfor se hva som taler for og mot demokrati i Sudan i dag.

Hva taler for demokrati? Sudan har i perioder vært styrt demokratisk. I henholdvis I956-1958, I964-1969 og I986-1989 var Sudan styrt av ulike demokratisk valgte regimer. Selv om disse regimene i lange perioder var avbrutt av militære diktaturer har Sudan hele tiden hatt relativt kompetente (om ikke lovlige) politiske partier og ledere. Et eventuelt fremtidig demokrati i Sudan kan derfor bygges på tidligere erfaring og kunnskap. Men vel så viktig som tidligere erfaring må vi også huske at ulike aktører faktisk jobber for demokrati i Sudan i dag. Spesielt må vi nevne fredsforhandlingene gjennom IGAD, samt politiske opposisjonsgrupper som NDA. Men også regimet i Khartoum er åpen for en videreutvikling av demokratiske institusjoner, først og fremst for å bedre sitt rykte utad.

Hva taler mot demokrati? Sudans president, Bashir, har på ingen måte vært den som har ivret sterkest etter demokratiske strukturer. Han er tross alt generalen som i snart I5 år har styrt Sudan. Han er relativt ung og har kontroll over hæren. Slikt sett har han både energi og virkemidler til å forsvare sin posisjon i mange år til. I tillegg har han hatt, og har, støtte fra både Egypt og USA. Ikke nødvendigvis fordi han er den beste til å styre landet, men han er av forskjellige grunner blitt foretrukket fremfor Turabi og islamistene. USA har med andre ord et særdeles ambivalent forhold til
Sudan. De ønsker både stabilitet, forutsigbarhet og demokrati i Sudan. Men når ikke alle tre ønsker er mulig å oppfylle samtidig, kommer dessverre demokrati i bakerste rekke. I tillegg er Sudan et stort land med en fattig befolkning preget av håpløshet på grunn av krig og vanstyre, med andre ord svært ugunstige forhold for demokratiutvikling.

\section{Utfallet av fredsforhandlingene}

Selv om demokrati ikke har vært Bashirs fanesak, er han åpen for en demokratiseringsprossess, en prosess som faktisk har pågått lenge $\mathrm{i}$ forbindelse med fredsforhandlingene mellom Nord- og SørSudan. Spesielt etter at Turabi forsvant fra den politiske scenen forsto Bashir at det nå var han som ville tjene på en pragmatisk tilnærming til demokratiske institusjoner. Han innså at en åpen holdning til demokrati ville styrke hans egen posisjon både regionalt og internasjonalt. Og selv om Bashir har egoistiske motiver, vil en demokratiseringsprosess definitivt gagne Sudan på lang sikt.

Fredsforhandlingene mellom nord og sør er ikke bare en prosess for å få slutt på borgerkrigen. Det forhandles også om hvordan det fremtidige Sudan skal organiseres politisk, og det har vært en selvfølge å følge demokratiske prinsipper. Bashir har dermed blitt tvunget til å tenke nytt i forhold til organiseringen av helt sentrale politiske institusjoner. Dette kom tydelig frem i løsningsingsforslaget som lå på bordet etter den andre runden med forhandlinger i Machakos høsten 2002. Blant annet er man blitt enige om å innføre et nytt senat med representanter fra alle regioner. I tillegg er man blitt enige om opprettelsen av et parlament i sør. Mye 
tyder derfor på at man er nær en fredsløsning - og dermed nærmere et reellt demokrati enn på lenge.

Likevel er det mange tekniske detaljer som kan velte forhandlingene. For eksempel spørsmålet om forholdet mellom parlamentene i nord og sør. Skal de likestilles, eller skal Khartoum være et nasjonalt parlament i tillegg til et parlament for nord?? $\mathrm{Og}$ hvis de likestilles, må man ikke da ha et

\section{man}

En ny runde med forhandlinger startet $i$ mars $i$ år, og mange håper på en løsning i løpet av våren.

tredje, overordnet parlament som binder landet sammen $?^{\text {ro }}$ Og hva med Khartoums stilling hvis det skal være landets hovedstad? Kan Sør-Sudan godta at hovedstaden styres av islamske lover, noe regimet i Khartoum ønsker? Eller hva med landets president? Vil regimet i nord kunne leve med at en representant fra sør en dag kan bli president? Tvilsomt. Derfor jobbes det intenst med å finne modeller der både sør og nord blir fornøyd med presidentembedet. Andre problemer som fremdeles står uløst er grensedragningen mellom nord og sør, samt fordelingen av oljeressursene.

Fordelen $\mathrm{i}$ dag er at forhandlingspartene, nemlig regjeringen i Sudan og SPLA, ikke lenger lider av alvorlige indre konflikter og stridigheter. Etter at Turbi ble kastet ut har Khartoum talt med én stemme, noe som også kan sies om SørSudan etter at SPLA nylig ble slått sammen med SSDF, et annet stort parti i sør. Både Khartoum og SPLA anerkjenner hverandre som reelle forhandlingspartnere, og grunnlaget er dermed lagt for dialog. I tillegg støttes fredsprossesen av de fleste både lokalt, nasjonalt, regionalt og internasjonalt - ihverfall sålenge landet forblir stabilt.

En ny runde med forhandlinger startet $\mathrm{i}$ mars $i$ år, og mange håper på en løsning $i$ løpet av våren. Slikt sett kan 2003 bli et spennende år for Afrikas største land. Kommer man frem til en holdbar politisk avtale vil både nord og sør binde seg til en visse demokratiske prinsipper. Kommer man derimot ikke frem til noen avtale, har Bashir frie hender til å fortsette som før. Med andre ord: En vellykket fredsavtale kan føre til gradvis innføring av demokrati. Hvis ikke vil vi sannsynligvis fremdeles oppleve et Sudan med kvasi-demokratiske strukturer der makten i Khartoum råder og borgerkrigen går inn i sitt tyvende år.

Claes-Johan L. Sørensen er M.A. i Political Science, AUB, Beirut og salgs- og markedsforingskonsulent i Norwegian Demining Consortium, Middle East

${ }^{\mathrm{I} B \mathrm{BBC}}$ News, "Sudanese Speaker Warns of Unrest,” I8. desember 1999. Tilgjengelig på "http://news.bbc.co.uk/hi/english/ world/africa/newsid_571000/571303.stm"

${ }^{2}$ Den islamske bevegelsen i Sudan har vært kjent under ulike navn siden starten på slutten av I940-tallet. Først brukte man betegnelsen Det muslimske brorskap, men skiftet i I964 navn til Islamic Charter Front (ICF) da bevegelsen ble politisert. I I985 skiftet man igjen navn, da til National Islamic Front (NIF), en paraplyorganisasjon og parti for en rekke islamistiske grupperinger. Denne betegnelsen brukes mest $\mathrm{i}$ dag selv om organisasjonen på 9o-tallet gikk under betegnelsen National Congress 
og siden Popular National Congress (PNC). det skulle oppstå interessekonflikter.

${ }^{3}$ Dette er selvfølgelig en forenkling. Både Turabi og Bashir har politiske og religiøse motiver, men hovedtrenden er etter mitt skjønn slik som nevnt ovenfor. Det er med andre ord ikke et forsøk på å over- eller undervurdere den ene eller den andres religiøse tro - som i seg selv vanskelig kan la seg måle.

4Inter-Governmental Authority on Drought and Development, fra 1996 Inter-Governmental Authority on Development, IGAD. Dagens medlemmer er Kenya, Etiopia, Uganda, Djibouti, Somalia, Sudan og Eritrea. Se www.igad.org

${ }^{5}$ Bashir fikk 75,7\% av stemmene i valget.

${ }^{6}$ Harvey Glickman: “Islamism in Sudan' s Civil War”. Orbis 44, no. 2 (Spring 2000): 280.

${ }^{7}$ BвC News, "Sudan Moves Turabi Out of Jail," May 30, 200I. Tilgjengelig på "http://news.bbc.co.uk/hi/english/world/ africa/newsid_I359000/1359552.stm"

${ }^{8}$ Se Hasan al-Turabi i «Mohamed Elhachmi Hamdi, The Making of an Islamic Political Leader: Conversations with Hasan al-Turabi», English Translation by Ashur A. Shamis, (Colorado and Oxford: Westview Press, 1998), 96-98.

${ }^{9}$ En slik modell kan sammenlignes med den norske. Vi har to parlament, henholdsvis Stortinget og Sametinget. Sametinget er på mange måter likestilt med Stortinget, men kan likevel bare overprove Stortinget i helt spesifikke saker hvis
${ }^{10}$ Denne modellen vil i så fall bety føderalisme slik de har i Tyskland eller USA. 